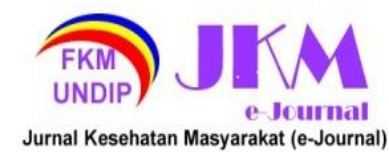

JURNAL KESEHATAN MASYARAKAT (e-Journal)

Volume 9, Nomor 5, September 2021

ISSN: 2715-5617 / e-ISSN: 2356-3346

http://ejournal3.undip.ac.id/index.php/jkm

\title{
FAKTOR-FAKTOR YANG BERHUBUNGAN DENGAN BURNOUT SYNDROME PADA PERAWAT DI RSUD BAHTERAMAS, SULAWESI TENGGARA
}

\author{
Wiwin Sujanah ${ }^{1}$, Arum Dian Pratiwi ${ }^{2^{*}}$, Akifah $^{3}$ \\ ${ }^{1}$ Peminatan Kesehatan dan Keselamatan Kerja, Fakultas Kesehatan Masyarakat, Universitas Halu \\ Oleo, Kendari, Indonesia \\ ${ }^{2}$ Bagian Kesehatan dan Keselamatan Kerja, Fakultas Kesehatan Masyarakat, Universitas Halu Oleo, \\ Kendari, Indonesia \\ ${ }^{3}$ Bagian Promosi Kesehatan, Fakultas Kesehatan Masyarakat, Universitas Halu Oleo, Kendari, \\ Indonesia \\ ${ }^{*}$ Coressponding author : arum.dian28@gmail.com
}

\begin{abstract}
Working as a nurse has the demands of heavy work in nursing care so that easy to experience fatigue can lead to burnout syndrome. Burnout syndrome is the occurrence of emotional fatigue, depressiveization, and decreased achievement of personal achievement due to stress that is often experienced by a worker and lasts a long time that causes negative attitudes towards a person. This study aims to find out the factors related to burnout syndrome in nurses in the Inpatient Installation of Bahteramas Hospital in Southeast Sulawesi Province. This type of research is observational analytics with a Cross Sectional Study approach. The population in this study was inpatient room nurses with a sample of 147 nurses selected with random sampling techniques. Data collection using maslach burnout inventory questionnaire, then analyzed using chi-square test. The results of this study showed that bound variables are associated with workloads with ( $p$-value $=0.000)$, dual roles ( $p$-value $=0.004$ ), personality types $(p$-value $=0.000)$ and there is no relationship between leadership style variables with burnout syndrome ( $p$-value $=0.164)$. The conclusion of this study is that there is a relationship between workload, dual role, and personality type with burnout syndrome, while the leadership style has no relationship with burnout syndrome in nurses in the Inpatient Installation of Bahteramas Hospital in Southeast Sulawesi Province. It is expected that the hospital needs to share the workload in accordance with the duties of nurses and the importance of nurses themselves make efforts to manage stress so that nurses can work well and can provide optimal services.
\end{abstract}

Keywords : Burnout syndrome, Workload, Dual role

\section{PENDAHULUAN}

Burnout didefinisikan dalam ICD-11 adalah syndrome yang digambarkan sebagai akibat adanya stres kronis yang belum berhasil ditangani dengan baik di temapat kerja yang ditandai dengan tiga dimensi yaitu perasaan lelah, perasaan negatif atau sinisme dan kinerja yang buruk di tempat kerja. Secara khusus burnout cenderung pada peristiwa dalam konteks pekerjaan. ${ }^{1}$ Burnout adalah bentuk yang parah dari tekanan psikologis yang timbul dari pekerjaan terkait trauma fisik dan mental, yang bermanifestasi sebagai kehilangan energi yang parah yang tidak dapat dikembalikan .2

Organisasi Kesehatan Dunia (WHO) mengatakan bahwa Burnout termasuk dalam revisi ke-11 dari International Classification of Diseases (ICD-11) sebagai fenomena kelelahan kerja, tidak diklasifikasikan sebagai kondisi medis ${ }^{1}$. Gejala burnout dapat ditandai dengan adanya kelelahan mental, kelelahan emosional dan pencapaian prestasi pribadi . ${ }^{3}$
Berdasarkan sebuah studi systematic review mengenai prevalensi burnout pada Dokter yang melibatkan 182 studi dari 109.628 individu di 45 negara dari tahun 1991-2018, prevalensi burnout yang dilaporkan adalah $67.0 \%{ }^{4} \mathrm{Di}$ Indonesia, berdasarkan penelitian pada tahun 2017 pada 138 perawat yang menangani pasien BPJS di Rumah Sakit Marinir Cilandak Tahun 2015 diketahui ada 79 responden (59,4\%) mengalami kejadian burnout berat dan sebesar 59 responden $(40,6 \%)$ yang mengalami kejadian burnout ringan. ${ }^{5} \mathrm{Di}$ Provinsi Sulawesi Tenggara, terdapat $15,7 \%$ perawat di RSJ mengalami burnout. ${ }^{6}$

Hasil survey awal kepada 10 perawat di Instalasi Rawat Inap RSUD Bahteramas terdapat perawat yang mengalami burnout syndrome pada dimensi kelelahan emosional sebanyak $0,3 \%$, pada dimensi depersonalisasi sebanyak $0,2 \%$ dan pada dimensi rendahnya prestasi pribadi sebanyak $0,3 \%$. Sedangkan yang tidak mengalami burnout syndrome sebanyak $0,2 \%$. Hal ini disebabkan karena 


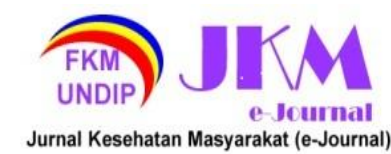

semakin meningkatya jumlah pasien setiap tahunnya dan sebagian perawat menyatakan terkadang sering mengalami stress saat tugas yang diberikan sudah terlalu banyak. Dengan meningkatnya beban kerja pada perawat dalam menjalankan tugasnya sehingga perawat mengalami kelelahan dan dapat menyebabkan burnout syndrome. Tujuan penelitian ini untuk mengetahui faktor-faktor apa saja yang berhubungan dengan burnout syndrome pada perawat di Instalasi Rawat Inap Rumah Sakit Umum Daerah Bahteramas Provinsi Sulawesi Tenggara tahun 2020.

\section{METODE PENELITIAN}

Penelitian ini merupakan penelitian kuantitatif dengan rancangan cros- sectional. Dengan pengumpulan data berupa variabel dependent dan independent yang dilakukan hanya satu kali dalam satu saat.

Jenis penelitian ini adalah observasional analitik dengan melakukan wawancara dan pengisian kuesioner. Populasi dalam penelitian ini adalah perawat yang bertugas di Instalasi Rawat Inap yang berjumlah 237 orang. Sampel dalam penelitian ini sebanyak 147 responden.

Teknik sampling yang digunakan dalam penelitian ini yaitu random sampling yang dilakukan secara acak. Instrumen pengambilan data menggunakan kuesioner. Variabel independen dalam penelitian ini adalah beban kerja, peran ganda, tipe kepribadian, dan gaya kepemimpinan. Untuk variabel dependennya adalah burnout syndrome. Pengolahan data : Editing, codding, entri, cleaning, dan tabulasi. Analisa data menggunakan analisis univariat dan bivariat. Analisis bivariat untuk menguji perbedaan atar variabel maka menggunakan uji Chi-square dan menggunakan $\alpha=0,05$

HASIL

Karateristik responden dalam penelitian ini meliputi umur, jenis kelamin, tingkat pendidikan, atatus perkawinan dan masa kerja. Hasil penelitian ini dapat dilihat pada tabel dibawah ini:

Tabel 1. Karakteristik Responden Pada Perawat di RSUD Bahteramas, Sulawesi Tenggara

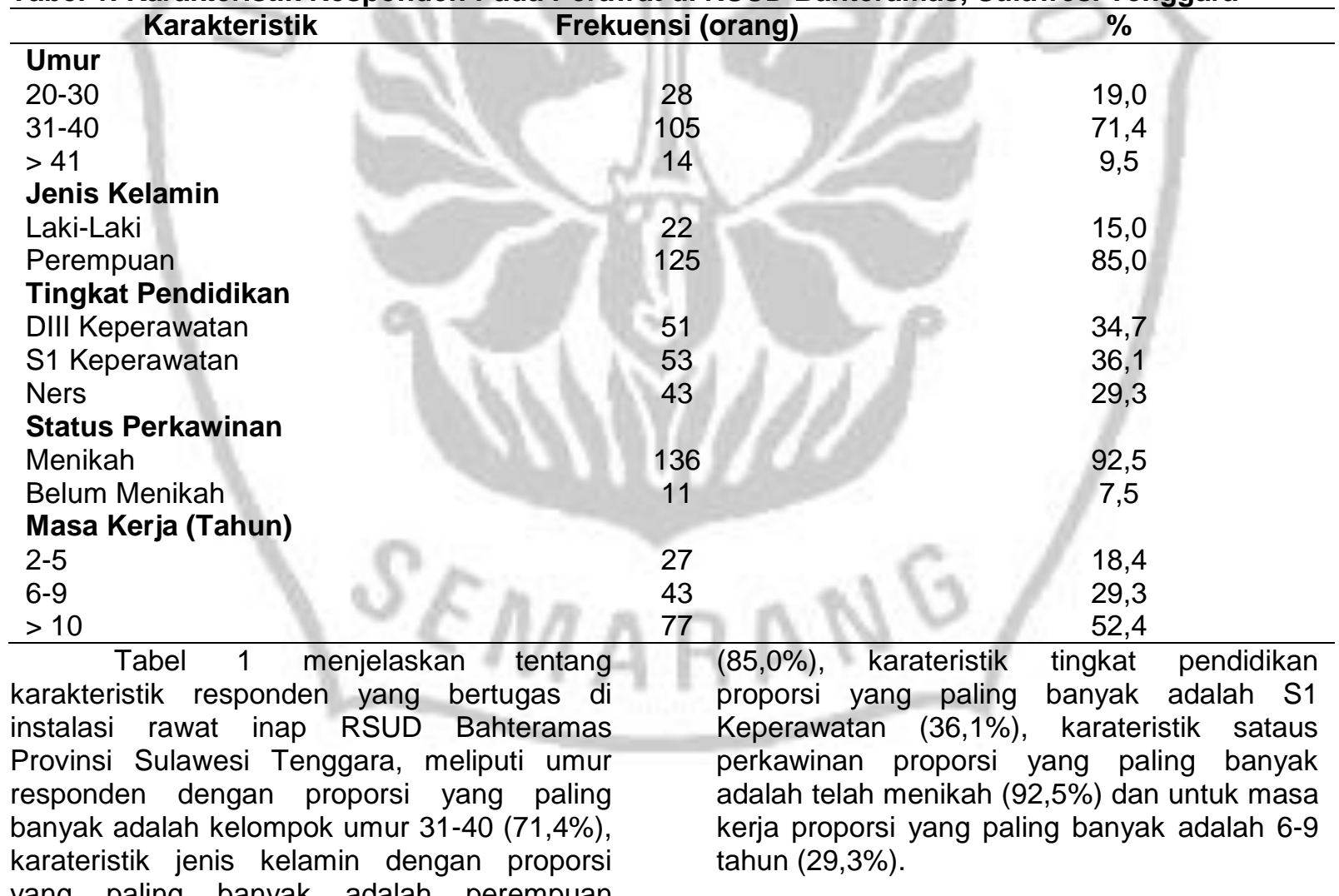




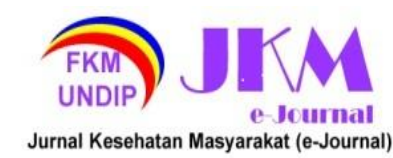

JURNAL KESEHATAN MASYARAKAT (e-Journal)

Volume 9, Nomor 5, September 2021

ISSN: 2715-5617 / e-ISSN: 2356-3346

http://ejournal3.undip.ac.id/index.php/jkm

Tabel 2. Hasil Analisis Faktor yang Berhubungan dengan Burnout Syndrome pada Perawat di RSUD Bahteramas, Sulawesi Tenggara

\begin{tabular}{|c|c|c|c|c|c|c|}
\hline \multirow{3}{*}{$\begin{array}{c}\text { Faktor-Faktor Burnout } \\
\text { Syndrome }\end{array}$} & \multicolumn{5}{|c|}{ Burnout Syndrome } & $\begin{array}{c}\mathbf{P} \\
\text { Value }\end{array}$ \\
\hline & \multicolumn{2}{|c|}{ Mengalami } & Tidak Mengalami & \multicolumn{2}{|c|}{ Jumlah } & \\
\hline & $\mathrm{n}$ & $\%$ & $n \quad \%$ & $\mathrm{n}$ & $\%$ & \\
\hline \multicolumn{7}{|l|}{ Beban Kerja } \\
\hline Berat & 56 & 65,1 & 34,9 & 86 & 100 & 0.000 \\
\hline Riangan & & & 70,5 & 61 & 100 & \\
\hline $\begin{array}{l}\text { Peran Ganda } \\
\text { Mengalami }\end{array}$ & & & 40 & & 100 & 0.004 \\
\hline Tidak Mengalami & & 32 & 67 & & 100 & \\
\hline Introvert & & 84,6 & 15,4 & 5 & 100 & 0.000 \\
\hline $\begin{array}{l}\text { Ekstrovert } \\
\text { Gaya Kepemimpin }\end{array}$ & & & & & 100 & \\
\hline Otokratis & 19 & 63,3 & 36,7 & 30 & 100 & 0.164 \\
\hline Demokratis & 55 & 47,0 & 53,0 & 117 & 100 & \\
\hline
\end{tabular}

Tabel 2 menjelaskan tentang hasil analisis bahwa responden dengan beban kerja berat sebanyak $65,1 \%$ mengalami burnout syndrome dan responden yang tidak mengalami sebanyak $34,9 \%$. Selain itu responden yang beban kerjanya ringan mengalami burnout syndrome sebanyak $29,5 \%$ dan reponden yang tidak mengalami sebanyak $70,5 \%$. Berdasarkan hasil uji Chisquare didapatkan bahwa nilai $(p$-value $=0,000)$ sehingga terdapat hubungan antara beban kerja dengan burnout syndrome pada perawat di RSUD Bahteramas, Sulawesi Tenggara.

Berdasarkan hasil analisis bahwa responden yang mengalami peran ganda sebanyak 59,2\% merasakan burnout syndrome dan responden yang tidak mengalami sebanyak 40,8\%. Selain itu responden yang tidak mengalami peran ganda merasakan burnout syndrome sebanyak $32,7 \%$ dan responden yang tidak mengalami sebanyak $67,3 \%$. Berdasarkan hasil uji Chisquare didapatkan bahwa nilai $(p$-value $=0,004)$ sehingga terdapat hubungan antara peran ganda dengan burnout syndrome pada perawat di RSUD Bahteramas, Sulawesi Tenggara.

Berdasarkan hasil analisis bahwa responden dengan tipe kepribadian introvert sebanyak $84,6 \%$ mengalami burnout syndrome dan responden yang tidak mengalami sebanyak $15,4 \%$. Selain itu responden dengan tipe kepribadian ekstrovert mengalami burnout syndrome sebanyak
$31,6 \%$ dan responden yang tidak mengalami sebanyak $68,4 \%$. Berdasarkan hasil uji Chisquare didapatkan bahwa nilai $(p$-value $=0,000)$ sehingga terdapat hubungan antara tipe kepribadian dengan burnout syndrome pada perawat di RSUD Bahteramas, Sulawesii Tenggara.

Berdasarkan hasil analisis bahwa responden yang menilai gaya kepemimpinan otokratis sebanyak $63,3 \%$ mengalami burnout syndrome dan responden yang tidak mengalami sebanyak $36,7 \%$. Selain itu responden yang menilai gaya kepemimpinan demokratis sebanyak $47,0 \%$ mengalami burnout syndrome dan responden yang tidak mengalami sebanyak 53,0\%. Berdasarkan hasil uji Chi-square didapatkan bahwa nilai ( $p$ value $=0,164$ ) sehingga tidak terdapat hubungan antara gaya kepemimpinan dengan burnout syndrome pada perawat di RSUD Bahteramas, Sulawesi Tenggara.

\section{PEMBAHASAN}

\section{Hubungan Beban Kerja Dengan Burnout Syndrome}

Berdasarkan hasil uji statistik diperoleh bahwa terdapat hubungan antara beban kerja dengan burnout syndrome pada perawat di RSUD Bahteramas, Sulawesi Tenggara dengan ( $p$-value $=0,000)$.

Hasil dalam penelitian ini didapatkan bahwa ada hubungan antara beban kerja dengan burnout syndrome. Hal ini dikarenakan adanya beban kerja yang diberikan terlalu 


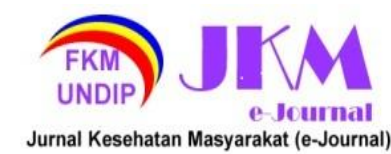

banyak dengan waktu yang mendesak untuk menyelesaikan pekerjaan tersebut. Sehingga dapat menimbulkan adanya pekerjaan kurang tepat (kesalahan) dan kelelahan. Dari kesalahan tersebut dapat membuat atasan dan keluarga pasien komplain pada akhirnya berdampak pada psikologis perawat sehingga menimbulkan stress yang berat dan mengalami burnout syndrome. ${ }^{7}$

Beban kerja yang berat memberikan pengaruh adanya burnout syndrome yang dialami oleh perawat salah satunya yaitu dimensi emotional exhaustion. ${ }^{8}$ Tingginya beban kerja yang dirasakan oleh perawat secara terus menerus akan menimbulkan kejenuhan dan kelelahan dalam tubuh sehingga akan mengalami stress kerja dan pada akhirnya cenderung merasakan burnout. ${ }^{9}$

Hasil penelitian ini sejalan dengan penelitian yang dilakukan oleh Nishimura tahun 2014 pada Dokter Jepang dengan hasil $(p$-value $=0,001) \cdot .^{10}$ Untuk mencegah timbulnya burnout syndrome maka perlunya keseimbangan antara keduanya dengan melihat kemampuan fisik, mental maupun emosional dari seorang perawat.

\section{Hubungan Peran Ganda Dengan Burnout Syndrome}

Hasil uji statistik diperoleh bahwa terdapat hubungan antara peran ganda dengan burnout syndrome pada perawat di RSUD Bahteramas, Sulawesi Tenggara dengan ( $p$-value $=0,004)$.

Hasil dalam penelitian ini didapatkan bahwa ada hubungan antara peran ganda dengan burnout syndrome. Hal ini dikarenakan adanya tanggung jawab dari setiap individu yang telah menikah dalam mengatasi permasalahan yang ada dan memiliki perbedaan atara sebelum menikah baik secara finansial maupun sosialnya. Peran sosial dapat dilihat dari partisipasi individu dalam organisasi maupun di lingkungan masyarakat. Individu yang sudah menikah mempunyai kewajiban untuk membantu mencari nafkah dan harus bisa menjalani peran sosial yang ada di lingkungannya, sehingga menimbulkan konflik peran. Baik konflik atar keluarga atau konflik anatar pekerjaan.

Kedua konflik tersebut akan memicu timbulnya stress kerja, karena apabila urusan pekerjaan ikut berperan dalam mencampuri kehidupan keluarga, individu akan merasa tertekan karena harus mengurangi waktu kerja yang dihabiskan dan begitupun sebaliknya. ${ }^{7}$ Seseorang perawat yang mengalami peran ganda akan kesulitan untuk membagi waktu dalam menjalankan dua peran dan tidak dapat fokus untuk satu peran, sehingga terjadi adanya tekanan yang bertambah dan merasakan kelelahan serta mengarah ke stres. Efek negatif dari stress yang mempengaruhi individu untuk mengalami burnout syndrome. ${ }^{11}$ Jika peran ganda ini tidak dapat dikontrol dengan baik maka dapat menimbulkan burnout syndrome.

Hasil penelitian ini sejalan dengan penelitian yang dilakukan oleh Khamndiniyati tahun 2019 yang menunjukkan ada hubungan peran ganda dengan kejadian burnout syndrome pada karyawan wanita menikah di Kalimantan Timur dengan hasil $(p$-value $=0,000)$ yang disebabkan karena adanya tekanan dari salah satu peran mempengaruhi kinerja peran yang lainnya..$^{12}$ Oleh karena itu perlu adanya upaya pencegahan agar burnout syndrome tidak dialami oleh seorang perawat salah satunya dengan cara adanya dukungan yang diberikan baik dukungan sosial dari tempat kerja maupun dukungan dari keluarga sehingga dapat menimbulkan kepuasan dalam bekerja.

\section{Hubungan Tipe Kepribadian Dengan Burnout Syndrome}

Berdasarkan hasil uji statistik diperoleh bahwa terdapat hubungan antara tipe kepribadian dengan burnout syndrome pada perawat di RSUD Bahteramas, Sulawesi Tenggara dengan ( $p$-value $=0,000)$.

Hasil dalam penelitian ini didapatkan bahwa ada hubungan antara tipe kepribadian dengan burnout syndrome. Hal ini dikarenakan bahwa seorang perawat yang memiliki tipe kepribadian introvert ketika menghadapi permasalahan akan dipendam sendiri tanpa mendapatkan solusi yang tepat untuk permasalahan yang dihadapinya. Apabila keadaan ini berlangsung lama maka dapat menimbulkan rasa lelah secara emosional. Keadaan lelah secara emosional yang dialami seorang perawat dengan sifat menutup diri dari lingkungannya maka akan merasakan kurangnya semangat dalam diri dalam menjalankan pekerjaannya.

Seseorang dengan tipe kepribadian introvert memiliki peluang yang tidak sedikit untuk merasakan emosi yang ada dalam dirinya karena dengan seseorang menutup diri dari lingkungannya cenderung merasakan depresi sehingga mengalami burnout syndrome. ${ }^{13}$ Burnout syndrome dapat memberikan dampak yang buruk kepada seorang perawat dengan tipe kepribadian 


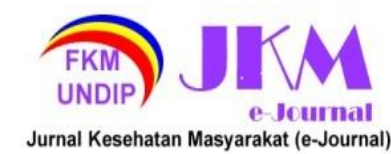

introvert, terutama berkaitan dengan kualitas pelayanan yang diberikan kepada pasien. ${ }^{14}$

Penelitian ini sejalan dengan penelitian yang dilakukan oleh Atia dan Soetjiningsih tahun 2020 yang menunjukkan ada hubungan tipe kepribadian dengan kejadian burnout syndrome pada perawat di RSUD Karanganyar dengan hasil ( $p$-value $=$ $0,002) \cdot{ }^{13}$ Oleh karena itu setiap orang yang mempunyai tipe kepribadian introvert harus mencoba terbiasa membuka diri dan bersosialisasi dengan lingkungan sekitar untuk mencegah tibulnya rasa tertekan dengan keadaan yang dihadapinya.

\section{Hubungan Gaya Kepmimpinan Dengan Burnout Syndrome}

Berdasarkan hasil uji statistik diperoleh bahwa tidak terdapat hubungan antara gaya kepemimpinan dengan burnout syndrome pada perawat di RSUD Bahteramas, Sulawesi Tenggara dengan ( $p$ value $=0,164)$.

Hasil dalam penelitian ini didapatkan bahwa tidak terdapat hubungan antara gaya kepemimpinan dengan burnout syndrome. Hal ini dikarenakan gaya kepemimpinan yang diterapkan oleh kepala ruangan adalah mayoritas demokratis. Oleh karena itu semakin rendah untuk perawat mengalami burnout syndrome. Kepemimpinan demokratis yang dimiliki seoarang pemimpin akan menerapkan bagaimana menghargai sifat dan kemampuan bawahannya serta memahami permasalahan yang ada dengan memecahkannya secara bersama-sama dengan bawahannya.

Gaya kempemimpinan demokratis dapat memberikan adanya dukungan sosial dari atasan kepada bawahannya sehingga berdampak positif terhadap burnout syndrome. ${ }^{15}$ Berbeda halnya dengan gaya kepemimpinan otokratis apabila semakin gaya kepemimpinan atasan otokratis itu tinggi, maka semakin meningkat pula burnout syndrome yang dirasakan oleh perawat. ${ }^{16}$

Penelitian ini sejalan dengan penelitian yang dilakukan oleh Danapour tahun 2018 yang menunjukkan tidak ada hubungan gaya kepemimpinan dengan kejadian burnout syndrome pelatih aquatik di Tehran, Iran dengan hasil $(p$-value $=0,029) .{ }^{17}$ Oleh karena itu dengan adanya gaya kepemimpinan demokratis sehingga perawat lebih santai dan nyaman dalam menjalakan tugasnya dalam melakukan perawatan pasien maupun menjalankan tugasnya yang lain dan tidak ada rasa tertekan dalam dirinya sehingga tidak dapat menimbulkan burnout syndrome.

\section{KESIMPULAN}

Berdasarkan penelitian yang telah dilakukan menunjukkan bahwa ada hubungan antara beban kerja, peran ganda dan tipe kepribadian dengan burnout syndrome. Keadaan ini dapat mempengaruhi kualiatas pelayanan yang ada dirumah sakit.

Upaya yang dapat dilakukan adalah perlunya pembagian beban kerja yang seimbang dan adanya manajemen stress yang harus dikelolah bagi setiap individu sehingga tidak menimbulkan adanya burnout syndrome.

Bagi peneliti selanjutnya agar dapat menganalisa lebih dalam mengenai faktorfaktor yang mempengaruhi terjadinya burnout syndrome, dengan pengambilan sampel lebih besar dan responden yang berbeda.

\section{UCAPAN TERIMA KASIH}

Terima kasih kepada seluruh staf dan Direktur RSUD Bahteramas Provinsi Sulawesi Tenggara yang telah membantu dan memberikan izin untuk melakukan penelitian hingga selesai.

\section{DAFTAR PUSTAKA}

1. WHO. Burn-out an "occupational phenomenon": International Classification of Diseases [Internet]. Available from: https://www.who.int/mental_health/eviden ce/burn-out/en/.2019.

2. Laukhi Msm. Burnout Syndrome In Health Care Professionals ( Nurses ) Of Private And Public Hospitals. IJRAR. 2020;7(1):464-7.

3. George Jones Jmgr. Understandng And Managing Organizational Behaviour. Sixth Edit. Yagan S, editor. Pearson Education; 2005; 1-190.

4. Aisyi M. Syndrome Burnout [Internet]. 2019. Available from: https://dharmais.co.id/news/117/SindromBurnout

5. Priantoro H. Hubungan Beban Kerja Dan Lingkungan Kerja Dengan Kejadian BurnOut Perawat Dalam Menangani Pasien BPJS. Jurusan IImu Kesehatan. 2017;16(3):9-16.

6. Dewi Gita Safitri. Waode Suarni CM. Peran Dukungan Sosial Dalam Memprediksi Burnout. Sublimasi. 2020;1(1):36-43.

7. Irma Refianti Manaf, Asyiah Simanjorang A. Faktor yang Mempengaruhi Stres Kerja Perawat Puskesmas di Wilayah Kerja 
Dinas Kesehatan Kabupaten Simeulue Tahun 2019. Jurnal Kesehatan Cehadum. 2019;1(4):9-20.

8. Kiekkas P. No Title. J Orthop Nursin [Internet]. Available from: https://pubmed.ncbi.nlm.nih.gov/2050549 1/. 2010;29(3):203-9

9. Sari D. Hubungan Beban Kerja, Faktor Demografi, Locus of Control Dan Harga Diri Terhadap Burnout Syndrome Pada Perawat Pelaksana Ird Rsup Sanglah. Coping Ners (Community Publ Nursing). 2015;3(2):51-60.

10. Nishimura K, Nakamura F, Takegami M, Fukuhara S, Nakagawara J, Ogasawara $\mathrm{K}$, et al. Cross-sectional survey of workload and burnout among japanese physicians working in stroke care. J Asp Study. 2014;7(3):414-22.

11. Putri AA, Mulyana OP. Hubungan Antara Konflik Peran Ganda Dengan Kecenderungan Burnout Pada Perawat RSUD Pamekasan. J Penelit Psikol. 2019;6(3):1-6.

12. Khamndiniyati N. Hubungan Peran Ganda dan Tipe Kepribadian DISC Terhadap Sindrom Kelelahan (Burnout). Psikoborneo. 2019;7(1):47-56.

13. Atia YSD, Soetjiningsih $\mathrm{CH}$. Burnout dan Kaitannya dengan Tipe Kepribadian Introvert. Psycho Idea. 2020;18(1):8-15.

14. Ambarita TFA. Perbedaan Burnout Antara Tipe Kepribadian Introvert Dan Tipe Kepribadian Ekstrovert Pada Perawat Di Ruangan Critical Care. 2017;100-14.

15. Nyoman Adinda Adnyaswari IGADA. Pengaruh Dukungan Sosial Dan Burnout Terhadap Kinerja Perawat Rawat Inap RSUP Sanglah. Med Chir Dig. 2017;6(5):2474-500.

16. Alif Fajri Husaeni AW. Pengaruh Gaya Kepemimpinan Dan Motivasi Terhadap Burnout Pada PT. Indaco Warna Dunia (Regional Sales Purwokerto). Rev Akutansi Kontemporere Indones. 2020;1(1):68-82.

17. Danapour M. The Relationship between Leadership Styles and Burnout of Aquatics Coaches in Tehran, Iran. Int Acad J Organ Behav Hum Resour Manag. 2018;5(2):99-109. 